\title{
ANALYSIS OF PEDAGOGICAL APPROACH FEATURES IN PHYSICAL EDUCATION OF PRE-SCHOOL AGED CHILDREN
}

\section{(C) I. Bogdanovskiy}

У статті уточнено актуальність та сутність формування педагогічного підходу у фізичному вихованні при заняттях з дітьми дошкільного віку. На сьогодні формування професійної компетентності майбутніх тренерів-викладачів для роботи в дошкільних навчальних закладах повинна базуватись на засадах теорії та методики фізичного виховання і спорту та вихідного стану організму дітей дошкільного віку

Ключові слова: професійна підготовка, педагогічний підхід, фізичне виховання, діти, дошкільний вік

We know that pre-school is one of the most critical periods of human life in formation of physical health, providing its improvement, strengthening and preserving in future, so the problem of formation of pedagogical approach to physical education of children of pre-school age at classes is seen to be actual. It is shown that in a definite pre-school necessary conditions were implemented and classes with sport games were carried out taking into consideration children state of health and their preferences. It is proved that during the year children's physical health indicators were significantly optimized-increased were the levels of physical development and percentage of harmoniously developed children, the number of children with stress adaptation mechanisms decreased, also levels of physical fitness increased and number of absenteeism due to illness reduced. It was established that professional training of future teachers-coaches in kindergartens should be based on the principles of the theory and methodology of physical education and sports and the initial state of health of pre-school aged children

In whole the results occured demonstrate the effectiveness of pedagogical approach to raising interest to physical activities and improving indicators of health level and can be recommended while training pre-school children.

Keywords: training, pedagogical approach, physical education, children, preschool age, physical health

\section{Introduction}

It is well known now that the pre-school age is one of the most critical periods of human life in the formation of physical health and skills of its support to ensure the strengthening and preservation in the future. Data of special profound studies [1] show that up to forty percent of adult diseases were «embedded» in childhood, namely in the pre-school period and health itselfby fifty percent depends on the way of life [2].

However, the increase of intelligent and informational stress nowadays that inevitably violate hygiene basics of mode of life of pre-school aged children, whose organisms by their morphofunctional and psychophysiological features and capabilities are far from maturity category, can lead to severe violations of physical and mental health. The increase of mental and physical activities in day regime in kindergartens can affect negatively on health of pre-school aged children. Children can overwork, their health and performance deteriorate as also like emotional well-being. These manifestations can cause school in future [3]. These manifestations can cause problems in adaptability of children to school conditions in future [3].

That is why pre-school physical education at preschools should form definite levels of child's health and physical culture foundation for future adult, that include: the positive attitude of children to physical exercises, sport games, tempering procedures, personal hygiene, adherence to day regime and informative interest to physical education.

For this a teacher-coach while following pedagogical approaches must be able to analyze and evaluate the physical health and motor development of children and formulate tasks of physical education for a certain period and determine primary ones having in mind peculiarities of every child. Also, a prerequisite is the ability to organize the educational process in particular, choosing the most appropriate means, forms and methods of work in specific circumstances. In addition, a teacher can project the desired level of the final result, anticipating difficulties in achieving the goals and compare the results achieved with the initial data and objectives [4].

Given that the physical education of pre-school aged children is a systematic affect on child's organism for the purpose of its morphological and functional improvement, health strengthening, formation of motor skills and physical qualities, the possession of selfappraisal of professional skills together with their constant improvement should be also regarded as features of pedagogical approach.

Due to the fact that during the pre-school childhood the health foundation is cared, the vital motor skills and abilities are formed and important physical qualities are being developed, it becomes actual to identify the effective ways ofpedagogical approach to physical education of pre-school aged children, which should con- 
tribute not only to recovery, but also to a full valuechild development.

\section{Literature review}

In modern pedagogical science researchers in physical education and sport a number of basic methodological approaches to determining of the nature and formation of professional competence of future specialists are stood out. Thus, considering the professional competence of teacher-coach one must remember that the focus of the educational system and the basic laws of its functioning are reflected in goals, objectives and general principles which form the base of teaching activities in physical education of the younger generation in our society, and the pre-school period has great plasticity and susceptibility to means ofphysical culture. At this time the best opportunities for implementation of sanitary, educational and teaching objectives are created [3].

In terms of today the science of physical education is developing rapidly and is constantly being updated by new data from research that involve philosophers, sociologists, educators, psychologists, biologists, doctors and representatives of other sciences. Thus researchers in theory and methodology of physical education summarize and creatively synthesize scientific information from related sciences $[5,6]$. The combination of scientific statements, which today constitute general theoretical concepts and applied scientific foundations of physical education and sports training in Ukraine are highly evaluated by specialists in the science world. Research works of national professors received recognition not only among Ukrainian school teachers, instructors and coaches but also among specialists in physical education abroad [7-9].

It is already proved that theory and methods of physical education has a close relationship with the general and pre-school pedagogy by using their creative achievements in all-round education of future generations. In physical education teaching and general educational principles and also methods and techniques of training and education are implemented. There is a lot of common between the theory and methods of physical education and general and age psychology. It is required to take into consideration the psychological characteristics of a child during different organizational forms of physical culture. Physical education has a great educational potential, it must be realized in the formation of child's will basing on the recommendations of psychology [10].

Close relationship between theory and methods of physical education and biological sciences is explained by the necessity to investigate a child's organism response to offered means of physical training. Only taking into consideration the anatomical and physiological laws of the child's organism one can successfully manage the process of physical education of pre-school aged children.

The analysis of scientific literature makes it possible to generalize that the National revival of Ukraine should require to solve the problems of national education and to update approach to physical education in the system of pre-school education. A modern teacher-coach should become a true master in his sphere with a high level of knowledge and skills in the field of educational activities. A necessary condition for the achievement of high professional and methodical training and skills for a teacher is mastering the basics of theory and methods of physical education and knowledge of anatomical, physiological and functional children development.

Actuality and practical importance of the problem justified the pedagogical approach to physical education in the formation of professional competence of future teacher-coach working with children of pre-school age. In the context of research the determination of features of components of the pedagogical approach to physical education of pre-school children is considered as a specially organized educational process in pre-schools, which involves a combination of traditional for this institution and interactive approaches and forms of physical activity directed to achieve the harmonious development of a child, and are aimed to acquire key competencies and professionally significant qualities of a teacher.

\section{Aim and research problems}

Aim - evaluation of the effectiveness of implementation of a new approach to physical education of pre-school aged children.

\section{Research problems:}

1) to review the literature on this problem;

2) to set the initial health state of pre-school aged children in conditions of pre-school institution;

3 ) to implement conditions and carry out classes of purposeful motor activity taking into account the state of health and preferences of children;

4) to form available insight and knowledge about the benefits of physical culture exercises and sports considering reasonable hygienic requirements and regulations;

5 ) to evaluate the effectiveness of pedagogical approach to raising interest to physical activity and improving the components of health level.

\section{Materials and methods}

To implement the program of research the following theoretical and practical methods were applied: analysis and synthesis of scientific literature on the problem under research (educational, medical, physical education and sports, functional diagnostics); study and theoretical understanding of the experience of pre-schools; synthesis, generalization and simulation of specialists' work with pre-school aged children; determiningof health level, adaptive abilities, physical development, functional state of elder pre-school children; specification and systematic approach to determine the features of the pedagogical approach to physical education while working with pre-school aged children.

\section{Results of the research}

Features of pedagogical approach in the formation of professional competence in physical education of pre-school children depend on mastering certain standard samples and standards of knowledge and skills in the theory and methodology of physical education, as well as taking into account the initial physical state of childrenwith whom physical training lessons are held. 
In connection with the above, at the beginning of our research the initial examination of 4-6 years old children in kindergarten was held and it showed that only $11 \%$ belong to the practically healthy group.

The author of the diagnostic program «Pupil», which was used in this study, found that children who have poor health are characterized by almost $100 \%$ probability of chronic diseases presence. The level of «below average» is usually defined with children inpremorbid state, and «average» level characterizes the group of risks. On the opinion of specialists in the sphere ensure the safety of a child and allow to consider him healthy, that corresponds to the statistical results of medical examinations in determining the level of health in Ukraine [4, 8].

Attention is drawn to the fact that nobody from pre-school aged children met the requirements of a high level. At the same time the total number of children with health level «low» and «below average» was $56 \%$, thus indicating a necessity to review the sports and recreation activities with children in pre-schools.

Also, also it is important that a teacher of physical education should to take into account the data of the functional state of the cardiovascular, respiratory and muscular external systems. In our case, the indicators characterizing the possibility of cardio-respiratory systemswere lower compared with the age norm for more than $40 \%$ of children that probably determine a low level of physical health.

In practice of pre-schools a significant decline in health level of children is determined in the process of adaptation to training loads. This is also evidenced by the evaluation of the adaptation of children to the training environment and education. We have found about $20 \%$ of children were in the state of adaptation mechanisms stress that determines the necessity for directional correction of their mental and physical development.

According to the evaluation results of types and dynamics of mental capacity it was found that $25 \%$ of children had the symptoms of fatigue. Questionnaires and immune blood test excluded likelihood of chronic fatigue syndrome, but the problem of chronic fatigue has identified the need to include a ratedphysical training exercisesin the day regime for all children. In particular, it was considered necessary to carry out movement hours, sport games and psychological correction.

We also found that the children efficiency after weekend remains at the level of the end of the week or is significantly lower. These data indicatelack of effective recreation of children that promotes fatigue to them.

We now know that one of the most important criteria of evaluating the health of children is their level of physical development. Disharmonious development is due to deviations of length and body weight from normal rates and is usually combined with various functional disorders of the body, reduction of mental and physical capabilities.

We have obtained the data that $73 \%$ of children developed harmoniously that corresponds to the results of other authors [2]. The main cause of disharmony is deviation of normal body weight (excessive or insufficient). The reasons of the tall stature of children should be explained by hereditary factors, in this connection it is advisable to calculate the estimated length of the child's body based on anthropometric data of parents or by accelerated development.

In the selection and dosage of physical activity ateacher-coach should also take into account the physical development of children. It is known that physical development is also characterized by some degree of physical (motor) skills (strength, speed, agility, flexibility, endurance), which all together give the idea of «physical fitness».

Today, as to the opinion of specialists in physical education and sports, it is accepted that the «medium» level of human health corresponds to at least «average» level of his physical fitness.

In making this argument for granted, we can assert that almost $70 \%$ of pre-school children is not sufficient to form the basis of good health. Compared to the age normalindiceschildren show reduced rates of strength, speed and especially physical endurance.

These facts having in mind it is extremely importanttoorganize efficiently the process of physical education, providing hygienically reasonable level of physical activity that promotes a comprehensive development of physical qualities of a child,formsthe optimal psychoemotional state and creates incentives to go in for some kind of sports.

Characterized results of pre-school children examination became the theoretical basis for the proposed structural model of pedagogical approach to physical education of this category of children.

As pre-schoolers eat at school, there is the unique opportunity of alimentary correction of weight using diet individualization. In particular, it is advisable to organize for children with overweight besides alimentary individualization an appropriate movingregime, that is characterized by excess of energy lossesover the quantity of caloriesin diet by $100-200 \mathrm{kcal} / \mathrm{day}$.

As a result of educational model implementation during the calendar year the number of children with poor rates of physical health decreased due to their transition to a higher level.

During this year the most part of children who increased their level of physical health up to indicators specific for healthy children. This fact clearly shows the effectiveness of used teaching approaches and the high sensitivity of a child to dosed physical exercises.

The changes mentioned are defined by optimization of indices as of physical development of children and also of the functional state of the organism. During the year, the percentage of harmoniously developed children increased to $83,5 \%$, which is not typical for the team where the purposeful corrective work is not carried out.

The number of children with overweight and underweight decreased, obviously, it is the result of the rationalization of alimentationin pre-school and physical education classes, which are regularly held according to the special program.

It was found that during the study children showed significantly normalized indices of the functional state of the organism, thus indicating the increased capacities of cardiovascular, respiratory and muscular system. 
As a result, optimization of children growth and development processes and also rationally used moving regime allowed to increase their level of physical fitness. During the year, physical fitness improved by $14,2 \%$, but it is less than the number of children who showed the increaseof physical health level. Obviously, the possibilities of fitness influence on children organism were not been implemented fully.

Despite the fact that physical education classes were conducted in dependence of the individual characteristics of a child, the results should be better. In our view, this is largely due to poor material and technical base of fitness - a small gym, absence of outdoor playgrounds, lack of necessary equipment and stock.

Integrative indicator of the effectiveness of the proposed pedagogical approach was the reduction of stress degree of children adaptation mechanisms and their morbidity.

The results indicate a significant reduction of stress adaptation mechanisms - the number of children with stress adaptation mechanisms decreased from $20 \%$ to $4 \%$, thus characterizing the efficiency of physical training events. It is essential that there were no children with poor adaptation or state of its collapse.

Also, the result of measuresoccurred was the reduction of the incidence of acute morbidity when preventive capabilities of pedagogical approach were implemented in full.

It is clear that the random selection of any pedagogical conditions cannot significantly influence the efficiency of formation of professional competence of the teacher-coach working with pre-school children. In this regard, the main factors that characterize our approach to the choice of pedagogical conditions are defined thus providing the relationship between all components of health - physical, mental, functional. All stated above, in its turn, contributes to achieve the goal of physical education, that is to educatehealthy and harmoniously physically developed child.

In the context of the study of pedagogical approach to physical education of pre-school aged children it was identified: respect to the fundamental principles of the theory and methodology of physical education and sports; definition of psychological, physiological and anatomical and functional initial state of pre-school aged children by appropriate to their age norms diagnostic methods; determining of the health level and the availability of the disease occurred; taking into account the child's age and preferences for a specific kind of sports, logistics of pre-school and time of year.

\section{Conclusion}

The above results led to some conclusions: at the beginning of the research children were devided in terms of physical health in a particular pre-school as follows «low» $24 \%$, «below average» $32 \%$, «average» $33 \%$, «above average» $11 \%$, that generally correspond to the results of examination of children in Ukraine.

Thus, harmonious physical development was found with $73 \%$ of children. The main causes of disharmony were deficiency and excess of body weight (14\% and $8 \%$ respectively). Also stress adaptation mechanisms were observed with $19 \%$ of pre-school aged children.

As a result of the use of pedagogical approach to physical education in pre-school - namely, implementation of conditions and carrying out classes in sports based on health state and preferences of children during the year optimized significantly the indices of physical health: level of physical development increased by $10 \%$ per cent, number of harmoniously developed children increased by $10 \%$ and at the end of the year amounted to $83 \%$, children with stress adaptation mechanisms reduced to four, level of physical fitness during the year increased by $14 \%$ and number of absenteeism due to illness decreased.

In whole, the results obtained demonstrate the effectiveness of pedagogical approach in raising interest to physical activity and improvement the health components and can be recommended for work with pre-school aged children.

\section{References}

1. Dudina, O. Situational Analysis of Children's Health [Text] / O. Dudina, A. Tereshchenko // Bulletin of Social Hygiene and Public Health of Ukraine. - 2014. - Vol. 2, Issue 60. - P. 49-57.

2. Annual Report on the State of Health, Sanitary and Epidemiological Situation and the Results of the Health Care System of Ukraine [Text] / O. Kvitashvili (Ed.). - Kyiv, 2015 - 460 p.

3. Vilchkovskiy, E. Theory and Methods of Physical Education of Pre-school Aged Children [Text] / E. Vilchkovskiy, A. Kurok. - Sumy: VTH «University Book», 2008. - 428 p.

4. Vorontsova, I. Features of Physical Education of Preschool Aged Children [Text] / I. Vorontsova, N. Prokopev // Young scientist. - 2014. - Issue 2. - P. 305-309.

5. Glazyrina, L. Methods of Physical Education of Preschool Aged Children [Text] / L. Glazyrina, V. Ovsyankyn. Moscow: VLADOS, 2005. $-176 \mathrm{p}$.

6. Komisaryk, M. Theory and Methods of Physical Education of Pre-school Aged Children [Text] / M. Komisaryk, G. Chuyko. - Chernivtsi: Books, 2013. - 484 p.

7. Minaev, B. Principles of Methods of Physical Education of Shoolchildren [Text] / B. Minaev, B. Shiyan. - Moscow, 2002. -455 p.

8. Apanasenko, G. Health Protection of Healthy Persons: Formulation of Problem in Ukraine [Text] / G. Apanasenko // Ukrainian Medical Journal. - 2009. - Vol. 4, Issue 72. P. 122-124.

9. Harrison, J. M. Instructional Strategies for Secondary School Physical Education [Text] / J. M. Harrison, C. L. Blakemore, M. M. Buck. - Ohio: McGraw-Hill Higher Education, 2005.

10. Zganyayiko, G. Mobile games [Text] / G. Zganyayiko, V. Postovalov. - Cherkasy, 2012. - 105 p.

\section{References}

1. Dudina, O., Tereshchenko, A. (2014). Situational Analysis of Children's Health. Bulletin of Social Hygiene and Public Health of Ukraine, 2 (60), 49-57.

2. Kvitashvili, O. (Ed.) (2015). Annual Report on the State of Health, Sanitary and Epidemiological Situation and the Results of the Health Care System of Ukraine. Kyiv, 460.

3. Vilchkovskiy, E., Kurok, A. (2008). Theory and Methods of Physical Education of Pre-school Aged Children. Sumy: VTH «University Book», 428.

4. Vorontsova, I., Prokopev, N. (2014). Features of Physical Education of Pre-school Aged Children. Young scientist, 2, 305-309. 
5. Glazyrina, L., Ovsyankyn, V. (2005). Methods of Physical Education of Pre-school Aged Children. Moscow: VLADOS, 176.

6. Komisaryk, M., Chuyko, G. (2013). Theory and Methods of Physical Education of Pre-school Aged Children. Chernivtsi: Books, 484.

7. Minaev, B., Shiyan, B. (2002). Principles of Methods of Physical Education of Shoolchildren. Moscow, 455.
8. Apanasenko, G. (2009). Health Protection of Healthy Persons: Formulation of Problem in Ukraine. Ukrainian Medical Journal, 4 (72), 122-124.

9. Harrison, J. M., Blakemore, C. L., Buck, M. M. (2005). Instructional Strategies for Secondary School Physical Education. Ohio: McGraw-Hill Higher Education.

10. Zganyayiko, G., Postovalov, V. (2012). Mobile games. Cherkasy, 105.

Рекомендовано до публікації д-р пед. наук, професор Конох А. П. Дата надходження рукопису 05.12.2016

Bogdanovskiy Igor, Postgraduate student, Department of theory and methodology of physical education and sport, Zaporizhzhya National University, Zhykovsky str., 66, Zaporizhzhya, Ukraine, 69600

E-mail: nadezhdabg2012@gmail.com

УДК 378.147 (73)

DOI: 10.15587/2519-4984.2016.87359

\section{ЗМІСТОВІ ЗАСАДИ ПРОФЕСІЙНОЇ ПІДГОТОВКИ МАЙБУТНІХ ФАХІВЦІВ ФІЛОЛОГІЧНОГО НАПРЯМУ У ВИЩІЙ ШКОЛІ США}

\section{(C) М. В. Іконнікова}

У статті досліджено зміст професійної підготовки філологів у системі вищої освіти США. Розкрито сутність поняття «курикулум» та його типи в американській дидактиці. Розглянуто основні наукові підходи (критеріальний, технологічний, мікрокурикулярний, макрокурикулярний) та принципи, на яких грунтується зміст професійної підготовки філологів. Охарактеризовано професійну компетентність та ії структуру, проаналізовано професійні компетенції майбутніх філологів

Ключові слова: філолог, професійна підготовка, наукові підходи, зміст, курикулум, професійні компетениіiі, США

The content features of philologists' professional training in the higher educational system of USA are presented in the article. The author considered the views of American scientists on the essence of notion "curriculum", its types (subject-oriented and profession-oriented). The content of future philologists' professional training was determined on the base of analysis of academic plans of American universities. The main scientific approaches (criteria, technological, micro-curricular and macro-curricular ones) and principles that the philologists' professional training is grounded on are considered. Professional competence and its structure is characterized, professional competences that are formed on the base of defined content of training (node, leader, special ones) are analyzed. The system of disciplines coding in American experience is described and basic cycles of disciplines for future philologists are analyzed

Keywords: philologist, professional training, scientific approaches, curriculum, professional competences, USA

\section{1. Вступ}

В умовах сучасного глобалізованого суспільства світова спільнота вимагає від фахівця-філолога глибоких професійних знань і розвинених здібностей, здатності до самовизначення в багатомовному полікультурному середовищі, інноваційного творчого мислення, оперування великими обсягами інформації, володіння методологією формальної та неформальної комунікації. Одним із шляхів підвищення ефективності професійної підготовки таких фахівців $€$ пошук нових підходів з орієнтацією на досвід високорозвинених країн. В аналізованому контексті наукове зацікавлення становлять досягнення США, оскільки ця країна має багаторічну історію зародження ступеневої освіти, є центром світової лінгвістики, здобула світове визнання за високі показники щодо професійної підготовки фахівців гуманітарних наук 3 філології. Поліаспектне дослідження та об'єктивне вивчення найкращих педагогічних здобутків американського досвіду сприятиме збагаченню наукових поглядів вітчизняних учених новими ідеями щодо трансформації змісту, удосконалення форм, методів і технологій, науково-методичного забезпечення професійної підготовки філологів. Зазначене вище засвідчує актуальність порушеної проблеми.

\section{2. Літературний огляд}

Упродовж останніх десятиліть українськими науковцями активно здійснюються дослідження 3 проблем професійної підготовки філологів у вітчизняному і зарубіжному досвіді. Наукову і практичну цінність мають дослідження американських учених [1-8]. Попри численну кількість наукових розвідок, присвячених проблемі професійної підготовки фахів- 